\author{
Hamza Ouarriche \\ Ph.D. student \\ Moulay Ismail University \\ Faculty of sciences \\ Morocco \\ Mohamed El Bouhali \\ Ph.D. student \\ Moulay Ismail University \\ Faculty of sciences \\ Morocco \\ Firdaouss Bouisfi \\ Ph.D. student \\ Moulay Ismail University \\ Faculty of sciences \\ Morocco \\ Mohamed Chaoui \\ Professor \\ Moulay Ismail University \\ Faculty of sciences \\ Morocco \\ Mohamed Hannaoui \\ Professor \\ Moulay Ismail University \\ Faculty of sciences \\ Morocco
}

\section{Numerical Simulation of Flow in Trapezoidal Labyrinth-Channels of Drip Irrigation}

The clogging of emitters has been considered as one of the most troublesome problems inhibiting the extension of drip irrigation. This paper investigates the flow field of water and behaviour of suspended particles in the trapezoidal labyrinth-channel. Computational Fluid Dynamics methods has been executed on liquid-solid two-phase flow in labyrinth-channel emitters. $R N G$ k- $\varepsilon$ turbulence model was used to evaluate four types of emitters that have the same characteristics and differ in the elbow width $S$. This study has shown that as the value of $S$ increases, the maximum velocity in the labyrinth-channel decreases and the number of vortices increases. However, emitter with a high $S$ value are more subtle to clogging. In addition, it was also observed that smaller diameter particles behave best when they pass through the channel and follow the streamline flow. As the particle diameters become larger, the particles tend to leave the mean stream and enter the vortex zones under the force of inertia. So, more suspended particles trapped in the vortex area, more the chances of emitter clogging increase. All of these furthermore confirm that vortex and low speed regions were the main causes leading to emitter clogging.

Keywords: irrigation, clogging, emitters, vortices, velocity, Computational Fluid Dynamic.

\section{INTRODUCTION}

Drip irrigation is a very efficient method of providing water and nutrients to plants [1], and is considered one of the most efficient irrigation techniques in the world, playing an environmentally active role in saving water and also in the use of wastewater.

The emitter is the critical part in drip irrigation system; it is aimed to let out the pressurized water in the pipe to drop into the soil gradually and regularly, the size of the emitter channels is around $0.5 \sim 1.0 \mathrm{~mm}$ [2]. It can be clogged by suspended particles originating from the filtering system easily. The clogging of emitters is the most important problem disturbing the lifespan and performance of drip irrigation systems. Since the first international conference on drip irrigation was held In Israel in 1971 [3], many challenges on resolving clogging problems have been shown by Bucks and Nakayama, Nakayama and Bucks, Mu et al., Duran-Ros et al. [4].

This phenomenon can be produced by physical, chemical or biological impurities [5]. The physical clogging is due to the deposition of suspended particles in irrigation water such as sand, clay and silt reaching in size from 1 to $300 \mu \mathrm{m}$. The chemical clogging is attributedto the interaction of dissolved solids and from

Received: April 2020, Accepted: September 2020

Correspondence to: Hamza Ouarriche

PhD student, Moulay Ismail University,

Faculty of sciences, Morocco

E-mail: ouar.hamza@gmail.com

doi: $10.5937 /$ fme21011470

(C) Faculty of Mechanical Engineering, Belgrade. All rights reserved precipitates, e.g. calcium carbonate, with a diameter of $1-74 \mu \mathrm{m}$. The biological clogging is due to the point that algae and bacteria having a size between 3 to $50 \mu \mathrm{m}$ breed and then built up in stagnation zones of emitters [6]. Physical clogging caused by solid particles is considered to be the most common form of plugging of emitters [7,8], and also the direct reason that caused the clogging of emitters [9]. Researchers have tried optimizing the sedimentation basin [10], choosing and uniting filters, and regulating the operation of the irrigation system to resolve the emitter clogging problem. Numerically, numerous studies have been performed based on computational fluid dynamics (CFD) to envisage and study the flow at the interior of the labyrinthchannel dripper $[11,12]$. These researchers detected that the flow can be divided into two parts: the main flow area is categorized by high velocity and the zones with vortices in channel corners [13]. Liu et al. (2010) [14] revealed that the main factors responsible for physical clogging are the particle diameters, the velocity of suspended particles, and sediment concentrations. The probability of emitter clogging is considerably increased when particle diameter surpasses $50 \mu \mathrm{m}$. However, emitters can also be clogged by the accumulation of fine particles such as silt and clay $[15,16]$. The average size of the labyrinth channel width is approximately $1 \mathrm{~mm}$ [17]. Niu et al. [18] detected that the deposition of particles is usually located at the inlet and channel corners.

The clogging of the emitters unfortunately has a negative impact on the pollution level, i.e. the lifetime of the drippers causes more dripper discharges and this will 
cause much more pollution. And to remedy this problem, it is necessary to design a dripper that can be more resistant to clogging and that will have al longer life span.

This study numerically investigates the performance of the emitter and the impact of the change in the form of channels on the flow.

\section{MATHEMATICAL MODEL OF THE FLOW}

In this study, a flat emitter was used as a physical prototype. Its flow rate was $3.5 \mathrm{~L} / \mathrm{h}$. The different dimensions of the emitter were taken by a microscope with an accuracy of $0.01 \mathrm{~mm}$. The specific characteristics and parameters of the flow path are shown in Figure 1.The trapezoidal emitter was modelled in $2 \mathrm{D}$ with a commercial CFD code, using a finite volume discretization method.

In this study, we also compared four types of channels that have the same structure and are differentiated in parameter $\mathrm{S}$ which is equal to $0 \mathrm{~mm}, 0.08 \mathrm{~mm}$, $0.1 \mathrm{~mm}, 0.2 \mathrm{~mm}$ and $0.4 \mathrm{~mm}$ as shown in the figure 2 .

The 2D modelling work has made it possible to more precisely characterize the hydrodynamics of these drippers. Although the Reynolds number is low, these simulations were carried out with a turbulent pattern. Indeed, the small flow section and the presence of channels favour a transition from laminar to turbulent [19] with low Reynolds number.

Droplet cross-sections are of the order of a millimetre and are at the limit of microchannels. For this type of flow, some experiments show a laminar/turbulent transition at a lower Reynolds number than the conventional value for macro-scales, which is 2300 [20] while others show no displacement of this transition [21].
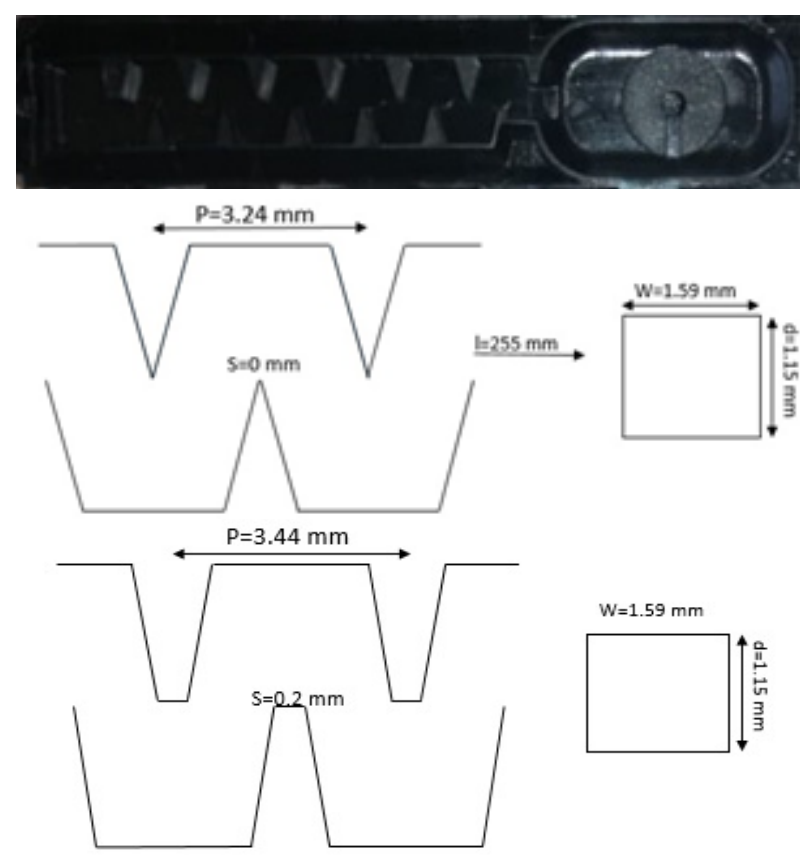

Figure 1. A schematic view of the parameters of emitter

Nishimura et al. (1984) [22] researched the wavy channels, and research results showed that in this complex channels the conversion from laminar to turbulent flow happened when the Reynolds number stretch to 350 , which was less than critical Reynolds number in straight channels.
The flow field emitter was simulated using the turbulence model in this paper. The flow comportment can be studied as a multiphase flow using either Euler-Euler or an Euler-Lagrange approach. In the actual application of emitters, the volume ration of sand to water is far less than $10 \%$ after filtering.

So the approach of Euler-Lagrange is taken on.

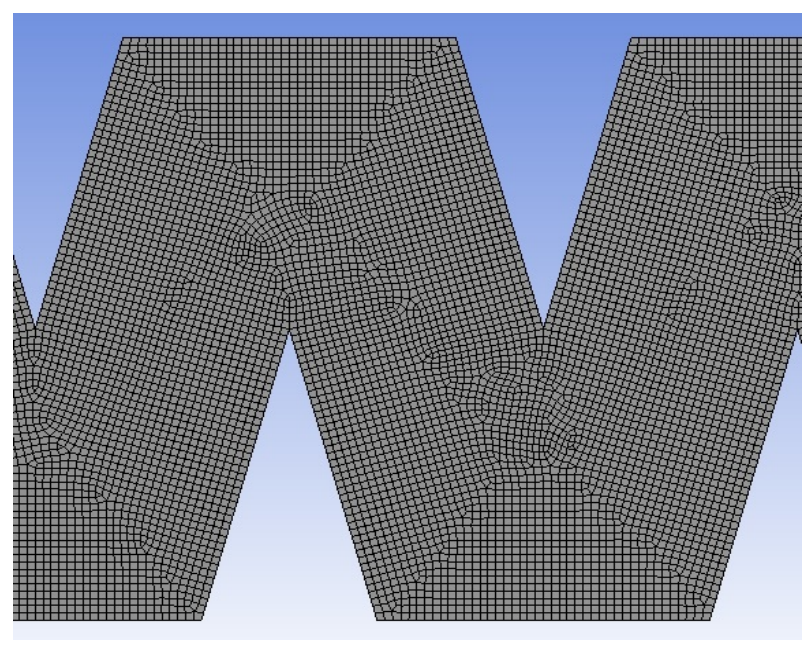

Figure 2. Emitter's labyrinth mesh

\subsection{Eulerian phase}

The fluid in the emitter is water, consequently, it can be supposed to be viscous, steady, incompressible and at room temperature.

Because of the nature of the emitter's material, which is plastic, the emitter has a low coefficient of surface roughness. Moreover, the effects of gravity are low. Therefore, the surface roughness on hydraulic performance and gravity are neglected.

The fluid field equations governing in an emitter are as following:

Continuity equation:

$$
\frac{\partial}{\partial x_{i}} \rho U_{i}=0
$$

Momentum equation:

$$
\frac{\partial}{\partial x_{j}} \rho U_{i} U_{j}=-\frac{\partial}{\partial x_{i}} P+\frac{\partial}{\partial x_{j}} T_{i j}+\rho g_{i}
$$

where:

$$
\frac{\partial}{\partial x_{j}} \rho U_{i} U_{j}: \text { Convective Term }
$$

$-\frac{\partial}{\partial x_{i}} P$ :Influence of pressure

$$
\frac{\partial}{\partial x_{j}} T_{i j}: \text { Diffusive term }
$$

$\rho g_{i}:$ Gravity effect

$\mu$ : Dynamic viscosity

$\rho$ : Density of fluid

The mean of the Momentum equation is written: 


$$
\rho \bar{U}_{j} \frac{\partial \bar{U}_{1}}{\partial x_{j}}=-\frac{\partial P}{\partial x_{i}}+\frac{\partial}{\partial x_{j}}\left(\mu \frac{\partial \bar{U}_{1}}{\partial x_{j}}-\rho \overline{u_{1} u_{j}}\right)
$$

In this study, RNG k- $\varepsilon$ turbulence model was used to close the model since this model Takes into account smaller turbulence scales and gives better results for rotating flows and for modelling entrained cavities. Transport equation for turbulent kinetic energy $\mathrm{k}$ and dissipation of turbulent kinetic energy $\varepsilon$ are described as follows:

$$
\begin{aligned}
& \frac{\partial}{\partial x_{i}}\left(\rho \kappa \bar{U}_{1}\right)=\frac{\partial}{\partial x_{j}}\left[\left(\mu+\frac{\mu_{t}}{\sigma_{\kappa}}\right) \frac{\kappa}{x_{j}}\right]+G_{\kappa}-\rho \varepsilon \\
& \frac{\partial}{\partial x_{i}}\left(\rho \varepsilon \bar{U}_{1}\right)=\frac{\partial}{\partial x_{j}}\left[\left(\mu+\frac{\mu_{t}}{\sigma_{\varepsilon}}\right) \frac{\varepsilon}{x_{j}}\right]+C_{1 \varepsilon}^{\prime} \frac{\varepsilon}{\kappa} G_{\kappa}-C_{2 \varepsilon}
\end{aligned}
$$

where:

$\mu_{t}:$ turbulent viscosity

$G_{\kappa}$ : the generation of turbulence kinetic energy due to the mean velocity gradients

The production term $G_{\kappa}$ is given by:

$$
G_{\kappa}=-\rho{\overline{u_{1} u_{j}}}_{\frac{\partial \bar{U}_{j}}{\partial x_{i}}}
$$

$C_{1 \varepsilon}^{\prime}$ and $C_{2 \varepsilon}$ are constant of turbulence model

$C_{1 \varepsilon}^{\prime}=C_{1 \varepsilon}-\frac{\eta\left(1-\frac{\eta}{\eta_{0}}\right)}{1+\beta \eta^{3}}$

$\eta=S \frac{\kappa}{\varepsilon}$

$S=\left(2 S_{i j} S_{i j}\right)^{1 / 2}$

$S_{i j}=\frac{1}{2}\left(\frac{U_{i}}{x_{j}}+\frac{U_{j}}{x_{i}}\right)$

$\mu_{t}=\rho C_{\mu} \frac{\kappa^{2}}{\varepsilon}$

$\mathrm{C}_{\mu}=0.085$

$C_{1 \varepsilon}=1.42$

$C_{2 \varepsilon}=1.68$

$\sigma_{\varepsilon}=\sigma_{\kappa}=0.7179$

$\eta_{0}=4.38$

$\beta=0.015$

\section{NUMERICAL SIMULATION}

\subsection{Grid independence study}

To simulate the flow compartment in trapezoidal emitter, numerous computational fluid dynamics (CFD) programs are obtainable. In this study, principal equations are resolved by the commercial CFD code ANSYS Fluent.

The labyrinth channel was decomposed in the numerical calculation model into inlets, wall and outlets.

In order to have a good meshing, each labyrinth was meshed according to the structured hexahedron grids. A grid independence study was performed to ensure the accuracy of the solution.
The selected grid in this study was comprised of 158223 hexahedral elements. The mesh is shown in fig. 2 .

The governing equations, which have been defined above, were discretized by the control volume numerical technique, and then the SIMPLE pressure-velocity coupling technique that was developed by Patankar [23] was employed in order to solve the discretized equation and the second order upwind was used for the momentum, turbulence kinetic energy and dissipation rate of turbulence kinetic energy. When the outlet flow rate was basically stable and the residual value was lower than $10^{-4}$, the iteration calculation was convergent.

\subsection{Boundary conditions}

For the flow field calculation, the initial inlet boundary condition was a uniform fluid velocity for the momentum equations according to the fluid flow rate through the emitter under normal working conditions.

The particle velocity at the inlet was assumed to be equal to the value of the fluid velocity because of the developing segment near the inlet. The initial boundary condition of outlet was treated as standard atmosphere for the fluid. Turbulence intensity and hydraulic diameter were calculated. On the wall surface, the velocity was considered to be zero (no-slip condition). The near-wall flow was calculated using the standard wall function.

\section{RESULT AND DISCUSSION}

Figure 3 shows the fluid pressure distribution obtained numerically in the symmetry plane, where the pressure values are all relative to the standard atmosphere. The pressure in the emitter drops from inlet to outlet because of the non-exchange of energy with the external environment. Along the direction of flow, the static pressure gradually decreases, and the pressure drop in each channel unit was almost equal.

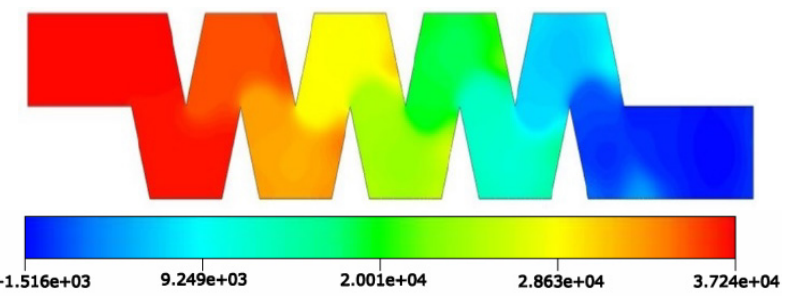

Figure 3. Pressure contour

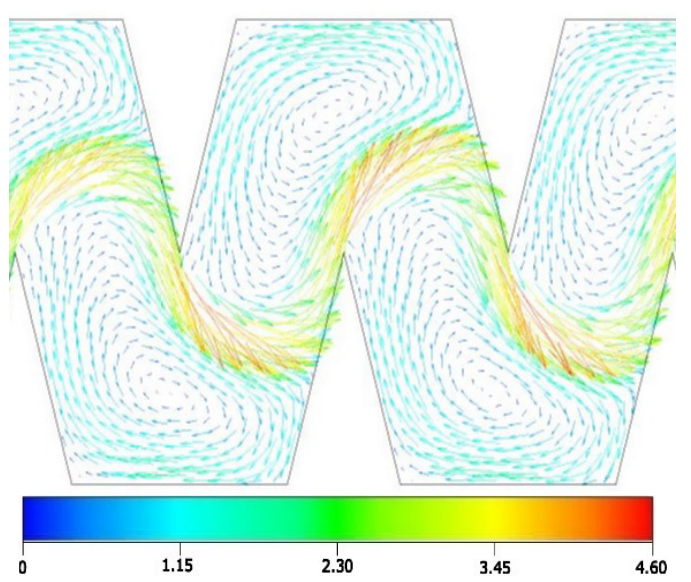

Figure 4. Velocity vector in the flow field 


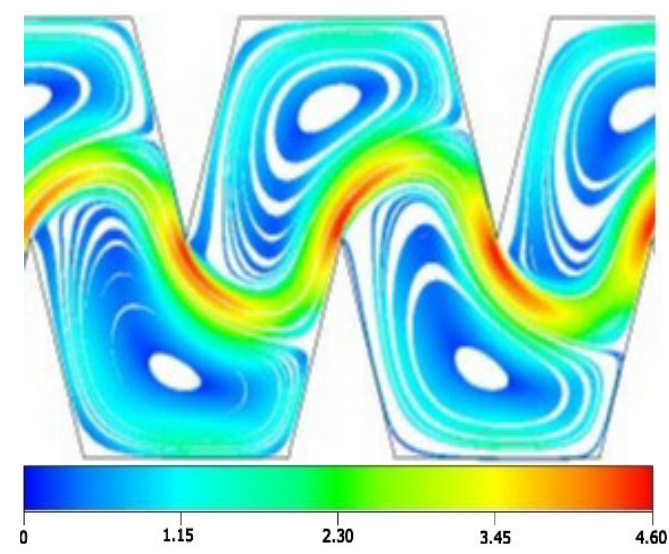

(a)- Case 1

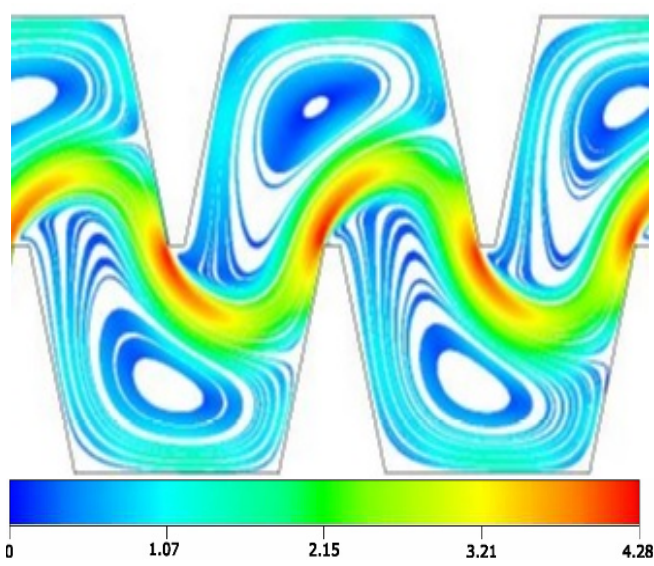

(b)- Case 2

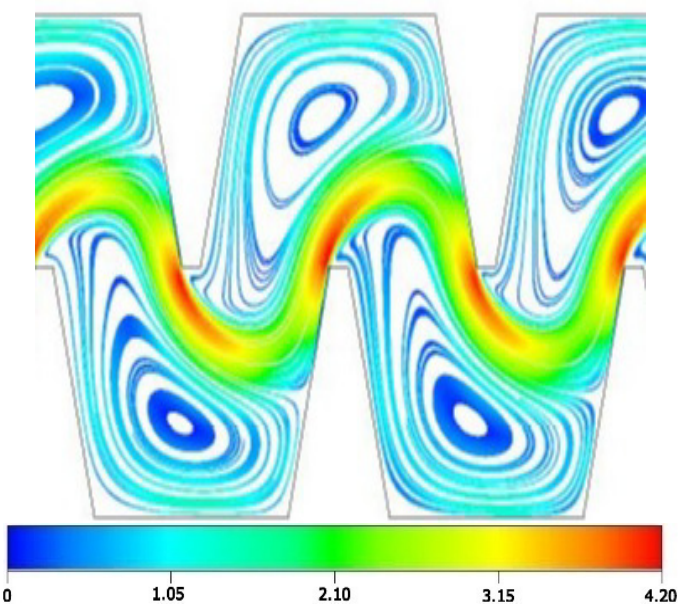

(c)- Case 3

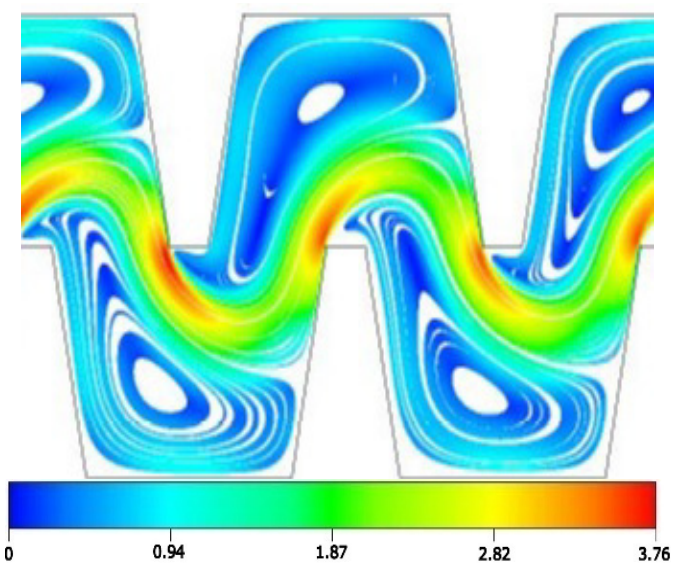

(d)- Case 4

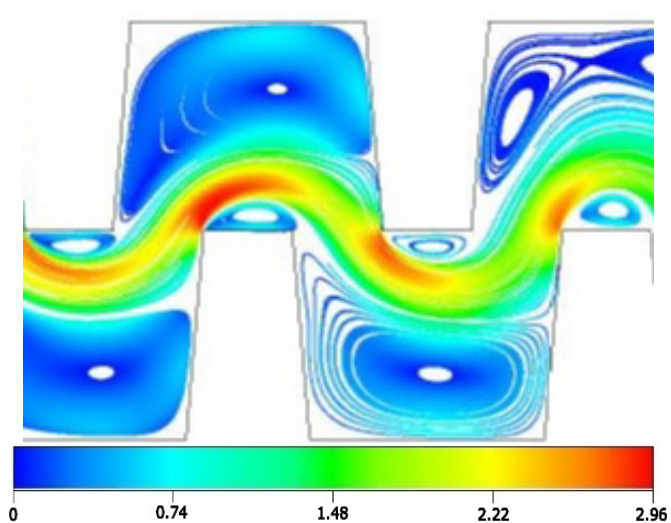

(e)- Case 5

Figure 5. Velocity distribution in flow field for standard geometry (a) and modified geometries (b), (c), (d), (e)

Figure 4 shows the streamlines of the water in the labyrinth, as shown the flow takes a rotational form in the vortex zones.

The following figure 5 shows the flow of fluid through the various channels.

Because the emitter contains several units with the similar structure, one unit was chosen as the analysis object. As shown above, the velocity of the fluid varies according to its position inside the channel.

From the figures, it can be observed that the region with high-velocity was located in the middle of the dripper labyrinth, whereas the low-velocity region was at the corner. While in the center of the vortex zone, the velocity was null. The figures also show that when we vary the dimension of $\mathrm{S}$ the speed varies, For $\mathrm{S}=0$, $0.08,0.1,0.2$ and $0.4 \mathrm{~mm}$, the maximum velocity is respectively $4.6,4.28,4.20,3.76$ and $2.96 \mathrm{~m} / \mathrm{s}$. In other words, when $\mathrm{S}$ increases, the maximum velocity of the fluid in the baffle becomes increasingly low. This also effects the pressure drops in the labyrinth channel.

It is obvious from the figures that there were four low-velocity regions in one trapezoidal labyrinth unit with $\mathrm{S}=0.4 \mathrm{~mm}$, but there were only two low velocity regions in one trapezoidal labyrinth unit with $S=0 \mathrm{~mm}$.

Once sands come into the vortex region or low velocity region, they were challenging to be flushed away. And with time passing, they would assemble together and finally creates the clogging. So it is indispensable to reduce the low-velocity regions and vortices in labyrinth channels in the design of emitter. Figure 6 shows the velocity variation curves along the labyrinth channel.

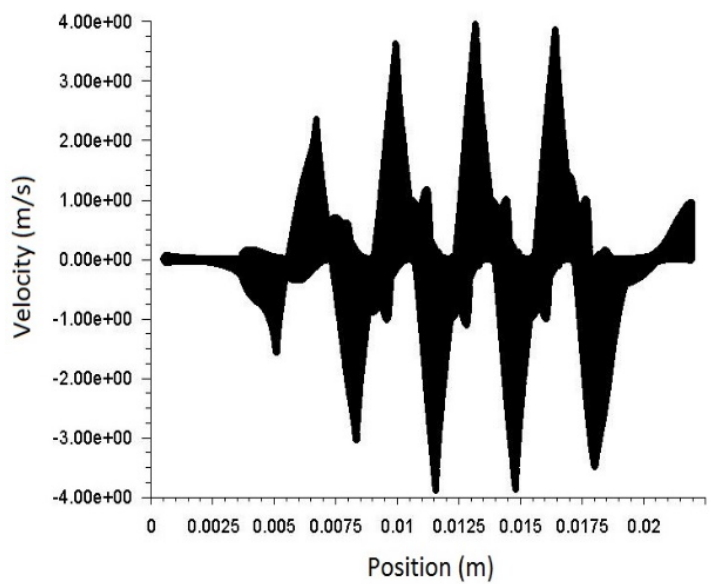



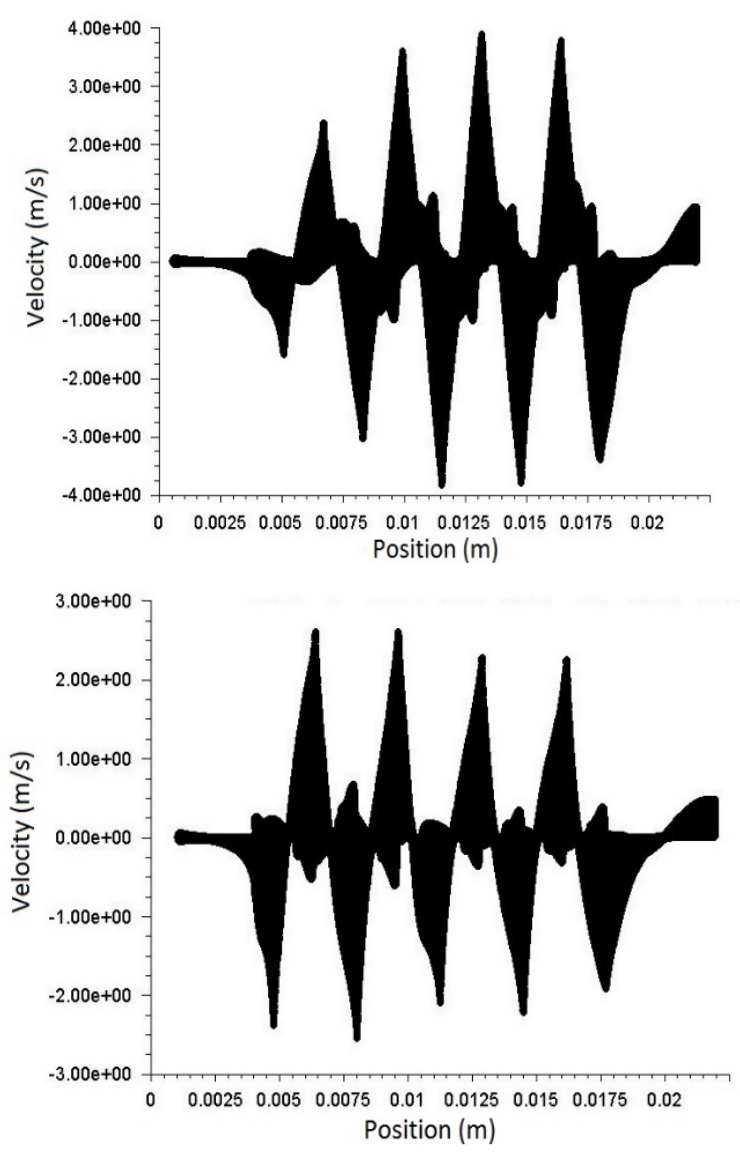

Figure 6. Velocity vector distribution in flow field for standard geometry (a) and modified geometries (b), (c), (d), (e), (f)

Figure 7 shows the variation of the speed as a function of $\mathrm{S}$. As mentioned above, the value of $\mathrm{S}$ has a great influence on the speed.

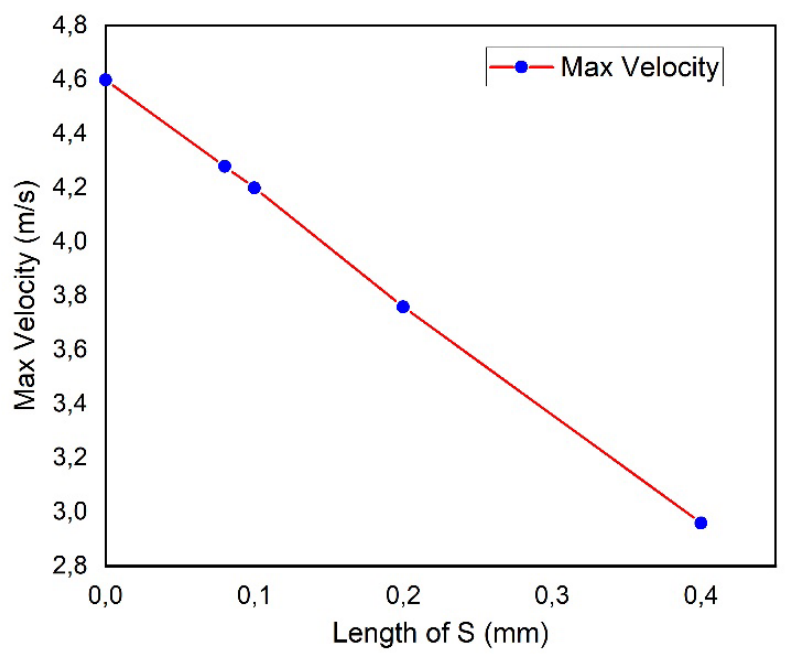

Figure 7. Variation of the maximum velocity in the labyrinth as a function of the length $S$

\section{DISTIBUTION OF PARTICLES IN MICRO CHANNELS}

The particles were injected from the inlet of the emitter and the initial velocity of the particles was assumed to be equal to the inlet velocity of the fluid

The figure 8 shows the path of suspended particles with diameters of $20 \mu \mathrm{m}$ and $120 \mu \mathrm{m}$ respectively in the dripper labyrinth.
As shown in the figure, the $20 \mu \mathrm{m}$ diameter particles follow the main stream of the fluid very well without penetrating the vortex. Thus, they demonstrate good behaviour and performance.

For particles with a diameter of $120 \mu \mathrm{m}$, they no longer follow the trajectory of the dominant current and the trajectory becomes more and more disturbing until they enter the vortex.

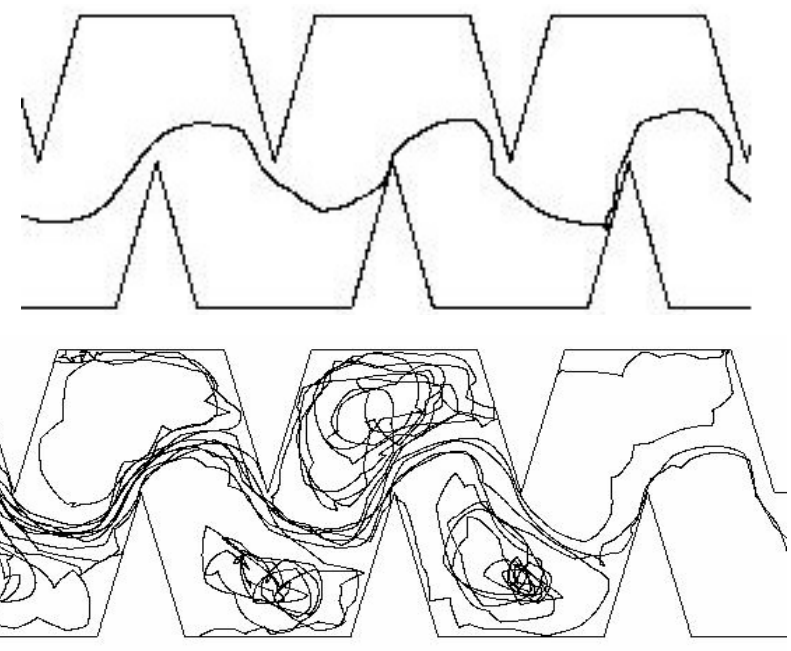

Figure 8.Trajectory of particles with diameters (a) $20 \mu \mathrm{m}$ and (b) $120 \mu \mathrm{m}$

The causes are that the drag force on sediments is relative to the square of the particle size. Nevertheless, the inertial force is proportionate to the cube sands diameter.

For particles of $20 \mu \mathrm{msize}$, the drag force was higher than the inertial force. Therefore, the sands moved only in the mean stream. As the diameters increased, the drag force and the inertial force tended to be equal. When the diameter reached $120 \mu \mathrm{m}$, the inertial force became the main force and exceeded the drag force. Particles tended to leave the main flow and enter the vortex zones under the effect of inertial force. Thus, the trajectories of the particles were disorganized. All sand movements had varying degrees of disturbance due to the rapidly changing flow directions in the channel.

All of these furthemore confirm that vortex and low speed regions were the main causes leading to channel clogging.

\section{CONCLUSION}

In this paper, a CFD numerical simulation performance was employed to investigate the flow field of water mixed with sand in the trapezoidal labyrinth-channel and the RNG k- $\varepsilon$ turbulence model was used to close the model. It was observed that the value of $\mathrm{S}$ influences the maximum velocity of the fluid flow in the emitter as well as the creation of vortices. It was also found that vortex and low speed regions were the main causes leading to channel clogging.

The emitters used in localized irrigation sometimes cause environmental problems because of the waste from the ramps and this is due to the lifetime of the emitters. For this reason, in order to reduce some of the pollution caused by these emitters, it is necessary to de- 
sign emitter structures that will have a longer life span and this will gradually reduce the pollution in this area.

\section{REFERENCES}

[1] Yun Kai Li Yao Ze Liu,Gui Bing Li, Ting Wu Xu, Hai Sheng Liu, Shu Mei Ren, Da Zhuang Yan, Pei Ling Yang: Surface topographic characteristics of suspended particulates in reclaimed wastewater and effects on clogging in labyrinth drip irrigation emitters IrrigSci 2012

[2] Zhengying WEI*, Meng CAO, Yiping TANG and Bingheng LU: Two-phase flow analysis and experimental investigation of micro-piv for emitter micro-channels. Seventh International Conference on CFD in the Minerals and Process Industries CSIRO, Melbourne, Australia 9-11 December 2009

[3] Yao ZX, Zhang WW, Zhang ZQ, Gao J Retrospection and suggestions of China's drip irrigation development process, 2011

[4] WenquanNiu, Lu Liu, Xue Chen: Influence of fine particle size and concentration on the clogging of labyrinth emitters, 2012

[5] Bucks DA, Nakayama FS, Gilbert RG.: Trickle irrigation water quality and prevention maintenance. Agricultural Water Management 1979; 2:149-162, 1979

[6] Adin A, Sacks M.: Dripper clogging factors in waste water irrigation. Journal of Irrigation and Drainage Engineering; 117:813-826, 1991

[7] Nakayama FR, Bucks DA: Water quality in drip/trickle irrigation: a review. IrrigSci 12(4):187192, 1991

[8] Pitts DJ, Haman DZ:Smajstrla AG Causes and prevention of emitter plugging in microirrigation systems. BUL258, Gainesville, University of Florida, IFAS, Extension, 2003

[9] Yan DZ, Bai ZH, Mike R, Gu LK, Ren SM, Yang PL: Biofilm structure and its influence on clogging in drip irrigation emitters distributing reclaimed wastewater. J Environ Sci 21(6):834-841, 2009

[10]Bouisfi, F., Bouisfi, A., Ouarriche, H., El Bouhali, M., Chaoui, M., Improving removal efficiency of sedimentation tanks using different inlet and outlet position Faculty of Mechanical Engineering, Belgrade. FME Transactions VOL. 47, No 4, 2019

[11] Wei Z, Cao M, Tang Y, Lu B: Two-phase flow analysis and experimental investigation of microPIV for emitter micro-channels. Seventh International Conference on CFD in the Minerals and Process Industries. CSIRO, Melbourne, Australia, 2009

[12] Al-Muhammad J, Tomas S, Anselmet F:Modeling a weak turbulent flow in a narrow and wavy channel: case of microirrigation. IrrigSci 34(5):361-377, 2016

[13] Nassim Ait Mouheb, Juliette Schillings, Jafar AlMuhammad, RyadBendoulal, Séverine Tomas, Muriel Amielh, Fabien Anselmet : Impact of hydrodynamics on clay particle deposition and biofilm development in a labyrinth-channel dripper, Springer-Verlag GmbH Germany, part of Springer Nature, 2018

[14] Liu HS, Li YK, Liu YZ, Yang PL, Ren SM, Wei RJ, $\mathrm{Xu}$ HB: Flow characteristics in energy dissipation units of labyrinth path in the drip irrigation emitters with DPIV technology. J HydrodynSer B 22(1):137-145, 2010

[15] Bounoua S, Tomas S, Labille J, Molle B, Granier J, Haldenwang P, NuurIzzati S: Understanding physical clogging in drip irrigation: in situ, in lab and numerical approaches. IrrigSci 34:327, 2016

[16] Oliveira FC, Lavanholi R, Camargo AP, Frizzone JA, Ait Mouheb N, Tomas S, Molle B: Influence of concentration and type of clay particles on dripper clogging. J Irrig Drain SystEng 6:184, 2017

[17]Zhang J, Zhao WH, Tang YP, Lu BH: Anticlogging performance evaluation and parameterized design of emitters with labyrinth channels. Comput Electron Agric 74:59-65, 2010

[18] Niu W, Liu L, Chen X: Influence of fine particle size and concentration on the clogging of labyrinth emitters. IrrigSci 31(4):545-555, 2013

[19]Zhang, J., Zhao, W.H., Tang, Y.P., Wei, Z.Y., Lu, B.H.,: Numerical investigation of the clogging mechanism in labyrinth channel of the emitter. International Journal for Numerical Methods in Engineering 70,1598-1612, 2007

[20]Pfund, D., Rector, D., Shekarriz, A.,: Pressure drop measurements in a microchannel. Fluid Mechanics and Transport Phenomena 46 (8), 1496-1507, 2000

$[21] \mathrm{Qu} \mathrm{W}$, Mudawar I Experimental and numerical study of pressure drop and heat transfer in a singlephase micro-channel heat sink. Int J Heat Mass Transf 45:2549-2565, 2002

[22] Nishimura T, Ohori Y, Kawamura Y. Flow characteristics in a channel with symmetric wavy wall for steady flow. Journal of Chemical Engineering of Japan; 17:466-471, 1984

[23] Patankar, S.: Numerical heat transfer and fluid flow, McGraw-Hill Book Company, New York, 1980.

\section{НУМЕРИЧКА СИМУЛАЦИЈА ПРОТОКА У ТРАПЕЗОИДНО ЛАВИРИНТСКИМ КАНАЛИМА КОД НАВОДЫАВАЊА КАПАЊЕМ}

\section{Х. Кварике, М.Ел Бухали, Ф. Боуисфи, М. Чауи, М. Ханауи}

Зачепљење капљача се сматра једном од највећих препрека проширењу система наводњавања капањем. Истражује се заливно поље и понашање суспендованих честица у трапезоидно лавиринтском каналу. ЦФД методе су примењене на проток кроз течност и чврсту подлогу код капљача лавиринтског канала. Помоћу РНГ к-є модела турбуленције извршена је евалуација четири типа капљача који 
имају исте карактеристике а различиту ширину заливне траке S. Истраживање показује да са порастом вредности $\mathrm{S}$ максимална брзина у лавиринтском каналу опада и повећава се број вртлога. Међутим, капљач са великом вредношћу $\mathrm{S}$ подложнији је зачепљењу. Такође је утврђено да се честице са малим пречником боље понашају при пролажењу кроз канал и крећу се у правцу тока струје. Честице већег пречника имају тенденцију да напусте средњу струју и уђу у зоне вртлога под утицајем инерције. Дакле, што је већи број честица накупљених у зони вртлога, већа је вероватноћа зачепљења капљача. Све наведено потврђује да су зоне вртлога и мале брзине главни узроци зачепљења капљача. 